\title{
Development of Warm-Up Models for Hockey Game
}

\author{
$1^{\text {st }}$ Novi Marlina Siregar \\ Study Program of Sport Recreation \\ Universitas Negeri Jakarta \\ Jakarta, Indonesia \\ novisiregar_fik96@yahoo.com
}

\author{
$2^{\text {nd }}$ Friska Restiani Faradita \\ Study Program of Sport Recreation \\ Universitas Negeri Jakarta \\ Jakarta, Indonesia \\ faradita84@gmail.com
}

\author{
$3^{\text {rd }}$ Hartman Nugraha \\ Study Program of Sport Recreation \\ Universitas Negeri Jakarta \\ Jakarta, Indonesia line 5:
}

\begin{abstract}
The study is aimed to make a warm-up game of hockey and improve motivation training, research for four months in September - December 2017. The research method is using the method of research and development $(R \& D)$, according to the Sukmadinata models, where this study uses three stages of the preliminary study, development, testing. The result of this research is producing products in the form of a warm-up game of hockey as much as $\mathbf{2 0}$ a models that has been tested in small groups involving 15 hockey athletes and test a large group, involving 30 hockey athletes. Before they were given a warm-up, researchers took the initial tests on motivation training, the pretest in the can of 3401. After that the application of the warm-up is done for eight sessions. The researchers did posttest to get results for score 3628 . The average pretest score 113.37, post test score 12.590 , and the test results $t$ is 9.737.Based on the results of research shows that the warm-up is to be applied and in use in improving motivation training. The end result of warm-up for hockey athletes in the form of a warm-up models.
\end{abstract}

Keywords - warming up, game, hockey state university of Jakarta introduction

\section{INTRODUCTION}

Hockey is one of the most popular sport of achievement, hockey game is played in teams using skin guard, ball, hand protection (glove), as well as stick that serves to hold, carry, and hit the ball.

The resounding achievement of Jakarta State University hockey shows that this team deserves to be called the best team in Indonesia. High school level students who cultivate hockey sports are many who enroll in the State University of Jakarta through the path of hockey sports achievements. The hockey team sporting exercise schedule is held every Tuesday, Thursday and Saturday at 4 pm-6pm at the Serba Guna (GSG) Faculty of Sports Sciences.

In general, before exercise or warm-up exercises first after it enters the core of exercise and the last cooling, heating is intended to stimulate the function of organs and prepare the condition of the muscles that is by heating the body temperature to avoid injury at the time of exercise.

At the time of warming the lack of variation in movement, the inner factor of the athlete due to the dense college activity makes the athlete feel tired for exercise accompanied by a warming movement that lacks an element of fun that seems exhausting, some athletes forget about warming because they are too eager to get into the core exercise. While athletes who come late to exercise they only make the movement sekedarnya because it was too late and immediately entered into the core exercise without thinking of the risks that will be experienced.

Moreover, if the exercise program is low intensity so that some athletes feel less warm up, to do the warming up movement needs motivation from within a person to do it seriously without any coercion.

\section{METHODS}

This research uses Research \& Development (R \& D) method to validate the product in the form of the development of warm-up model for hockey game for hockey athletes State University of Jakarta. According to Borg \& Gall R \& D in education is an industry-based development model where research findings are used to design new products and procedures, which are then systematically tested in the field, evaluated and refined to meet certain criteria

Design in research and development is based on systematic data derived from practice. Through systematic study there is a design, development and evaluation process with the aim of establishing an empirical basis for creating instructional and non-instructional products as well as new and improved tools and models. This is a way to test the theory and to validate the product, in addition to creating new procedures, techniques and tools based on specific analysis. Product design and development as well as instructional programs are at the heart and IDT (Instructional Design \& Technology).

Stages of this research is a procedure taken in making the development of warm-up model for hockey game. The end result of this study is to provide knowledge to the athletes hockey State University of Jakarta about the heating is very important and heating can be done through the game. 


\section{RESULTS}

\section{A. Results of Needs Analysis}

Needs analysis on warm-up model for hockey game research at hockey sports clubs State University of Jakarta aims to analyze the needs of the warm-up model to be done

The results of needs analysis in this study using interview data with sports club coach hockey achievement State University of Jakarta on December 5, 2017. Here described the results of needs analysis obtained by researchers.

\section{B. Early Product Creation}

After completion of the needs analysis phase continued with the initial product creation. The results of the needs analysis encourage researchers to make a model of warm-up hockey game with 20 models of warm-up.

\section{Expert Evaluation}

Before the game model that has been made can be declared valid and feasible to be tested to the subject of research, the researcher first perform the validation or feasibility test warmup models for hockey game to two experts: 1 expert game, 1 expert hockey. Both experts assess the design of the model made so it will be worth to be tested. Based on expert test conducted can be drawn the conclusion that there are 20 models of decent warm up in trial.

Warm-up model for hockey game for hockey athletes State University of Jakarta is feasible and can be used for heating.

Expert tests conducted by researchers on two experts there are some suggestions that build to refinement Warm-up models include:

1. Game experts suggest to sort the game from the easiest level up to the difficult level.

2. Expert Hockey advises on some games to pay attention to when the game begins not to be left too long queue up to wait their turn.

\section{Product Revisions}

Based on the data collected from each expert, there are several product designs that need to be revised before becoming a final model and tested in small groups. The product revision is intended to make the product design more perfect.

Based on the results of small group experiments conducted by researchers that 20 models of warm up done feasible to use and can be tested to the next stage is a large group trial.

\section{E. Hockey Game Warming Up Models}

1. Kucing dan Tikus

2. Bola Punggung

3. Zigi-zaga

4. Tiup Gerak

5. Kompas

6. Melangkah melewati rintangan

7. Bercermin

8. Putar Pinggang
9. Membuat Pyramid

10. Mengisi kotak tic tac toe

11. Mencari Warna

12. Memberi Bola

13. Terowongan Bola Berantai

14. Jalan Kepiting

15. Berputar Mendapatkan Bola

16. Balapan Ular

17. Mengejar Balon

18. Keranjang Bola

19. Estafet Bola

20. Mengoper Bola

\section{CONCLUSION}

Based on data on the research results that have been validated experts there are 20 models of warm-up. Small group trial with 15 random samples, tested by 20 models of warm-up, so large group trials of 30 random samples and 120 models of warm-up, as well as discussion of the results of the study, the researchers can draw the conclusion that:

1. Warm-up models for hockey game can be developed and applied in the sports practice of ihockey achievement sport of Jakarta State University.

2. Warm-up models for hockey game that has been developed, obtained the data of effectiveness and the results of Warmup models for sports club hockey achievement State University of Jakarta.

\section{REFERENCES}

[1] Aisyah, Siti, Development of Students \& Tutoring, Yogyakarta: deepublish, 2015.

[2] Feri, Kurniawan, "Book of Sport Knowledge" IEEE Transl. Buku Pintar Pengetahuan Olahraga, Jakarta: Laskar Aksara, 2012.

[3] FIH, Rules of Indoor Hockey, Effective, 1 January 2017.

[4] Harsono, Sports Coaching Theory and Methodology, Bandung: PT Remaja Rosdakarya, 2015.

[5] Hasibuan, Malayu S.P., Organization \& Motivation Base of Productivity Improvement, Jakarta: PT Bumi Askara, 2010.

[6] Komarudin, Sport Psychology, Bandung: PT Remaja Rosdakarya, 2013.

[7] Mulyatiningsih, Endang, Applied Research Methods Field of Education, Bandung: Alfabeta, 2012.

[8] Personal, Benny A, Model Learning System Design, Jakarta: Dian Rakyat, 2009.

[9] Siregar, Nofi Marlina, The Playing Theory, Jakarta: Prodi Sports Recreation, 2013

[10] Sugiyono, Qualitative and Quantitative Research Methods R \& D, Bandung: Alfabeta, 2008

[11] Sunyo, Adji Purnomo, 50 Games For Fun Learning and Teaching, London: YRAMA WIDYA, 2013

[12] Sukmadinata, Educational Research Methods, Bandung: PT Remaja Rosdakarya, 2011.

[13] Widya, Djumidar A, Tirto Apriyanto, Fitri Lestari Issom. Psychology of Sport, Jakarta: Faculty of Sport Science, 2012.

[14] http://www.flh.ac/en/fih/history/indoorrules (accessed December 17, 2016)

[15] http://www.vovo.co.id/2015/12/sejarah-and-technique-basichoki.html (accessed on October 11, 2017).

[16] https://www.kompasiana.com/finnyrizkiahputri/characteristicsmahasiswa-ideal (accessed on October 20, 2017). 